UDC 620.3

\title{
Chladni Figures Simulation on a Rectangular Plate
}

P. I. Krysenkof, ORCID 0000-0002-5612-9474

M. I. Zoziuk, ORCID 0000-0001-9116-7217

O. I. Yurikov, ORCID 0000-0001-8620-9902

D. V. Koroliuk ${ }^{\mathrm{s}}$, PhD, ORCID 0000-0003-2765-3450

Yu. I. Yakymenko, Dr.Sc.(Eng.) Prof., ORCID 0000-0002-8129-8616

National technical university of Ukraine "Igor Sikorsky Kyiv Polytechnic Institute" ROR 00syn5v21

Kyiv, Ukraine

\begin{abstract}
An analytical model for creating flat Chladni figures is presented. The equation of a standing wave in the simplest boundary conditions and the Fourier transform are used. Top view images are shown at different frequencies. The practical significance of the results obtained for the further development of the field of creating Chladni figures based on standing waves of different physical nature has been determined.
\end{abstract}

Keywords — standing wave; Chladni figures; metasurface.

\section{INTRODUCTION}

Recently, many methods have been demonstrated for creating metasurfaces for various purposes, for example, efficient absorption of solar energy [1], control of transverse vertical waves [2], multiband superabsorption and terahertz sensing [3]

Ernst Chladni in the 18th century showed amazing images on a plate, in the center of which there is a source of periodic pulses, and in which an acoustic standing wave is created (shown in Fig. 1). A bulk material (for example, sand) is placed on such a plate, which, in accordance with the configuration of the standing wave, occupies the most energetically optimal location, and a standing wave pattern is observed.

The mathematical modeling of Chladni figures was considered in a number of works, in particular in [4] - [7]. This article proposes a general model for both acoustic effects on bulk material and electromagnetic effects on a finely dispersed ferromagnetic powder or melt on a dielectric matrix [8].

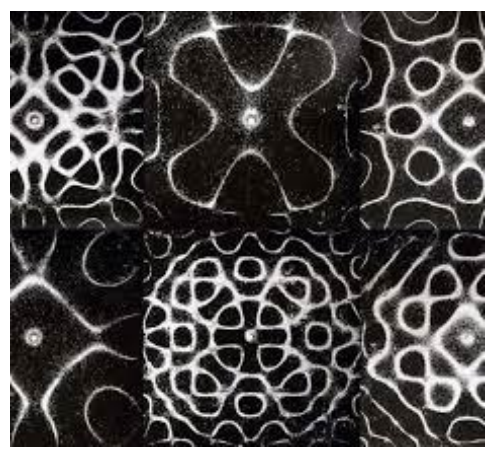

Fig. 1. Chladni figures at different frequencies of excitation.
In this article, adequate, but not universal, analytical models for the creation of Chladni figures are built, since they did not take into account the nature of the waves, the structure of the plate, the material, the parameters of environment, etc. This article discusses a method for creating metasurfaces based on Chladni figures. A brief analysis of this method is carried out - what are its limitations and difficulties. An analytical model for constructing a top view of Chladni figures using a stationary wave model is presented. On the basis of the analytical model, a number of Chladni figures are constructed for some combinations of the values of the model parameters. The values of the parameters were chosen from the point of view of practical interest, based on the effect of increasing the complexity of the pattern and the number of transition lines of standing waves (inflection lines of the density gradient of redistributed surface masses).

The figures are presented for one plate at different frequencies, which are determined using two parameters of the model. Our model describes the formation of Chladni figures through simplifying assumptions, and allows their numerical simulation in terms of coefficients that can be interpreted as environmental parameters or can be derived using them.

\section{CHLADNI FIGURE SIMULATION MODEL}

A rectangular plate with the size $1 \times 1$ is modeled. To build the model, the mechanism of transformation of a traveling wave into a standing wave is used, i.e. after some time after changing the excitation frequency, a standing wave is formed. This assumption is due to the practice of creating Chladni figures under the same experimental conditions.

Under external frequency action, a harmonic process of displacement of the plate $h$ along $z$ : 


$$
h(x, y, t)=\sin (2 \pi f t) s(x, y),
$$

where $f$ is the frequency of the exciting wave, $s(x, y)$ is the displacement coefficient.

In this case, the standing wave provides a time-stationary displacement coefficients $(x, y)$, which "normalizes" the periodic function $\sin (f, t)$. That is, there is a factorization of the displacement function by two factors, where the first depends only on time, and the second only on coordinates.

It is known [9] that the displacement function $\mathrm{h}$ is represented by the solution of the wave equation:

$$
\frac{\partial^{2} h}{\partial t^{2}}=c^{2}\left(\frac{\partial^{2} h}{\partial x^{2}}+\frac{\partial^{2} h}{\partial y^{2}}\right),
$$

where $c^{2}=1 / v^{2}, v$ be the velocity of the wavefront of the disturbance frequency $f$.

Note that

$$
\begin{gathered}
\frac{\partial h}{\partial t}=s 2 \pi f \cos (2 \pi f t), \\
\frac{\partial^{2} h}{\partial t^{2}}=-s 4 \pi^{2} f^{2} \sin (2 \pi f t),
\end{gathered}
$$

and also

$$
\left\{\begin{array}{l}
\frac{\partial^{2} h}{\partial x^{2}}=\sin (2 \pi f t) \frac{\partial^{2} s}{\partial x^{2}} \\
\frac{\partial^{2} h}{\partial y^{2}}=\sin (2 \pi f t) \frac{\partial^{2} s}{\partial y^{2}}
\end{array},\right.
$$

where $s(x, y)$ is the displacement coefficient

From (2), (4) follows the relation

$$
-s(2 \pi f t)^{2} \sin (2 \pi f t)=c^{2} \sin (2 \pi f t)\left(\frac{\partial^{2} s}{\partial x^{2}}+\frac{\partial^{2} s}{\partial y^{2}}\right),
$$

whence we have

$$
-\left(2 \pi \frac{f}{c}\right)^{2} s=\left(\frac{\partial^{2} s}{\partial x^{2}}+\frac{\partial^{2} s}{\partial y^{2}}\right) .
$$

Thus, the stationary wave model is reduced to an eigenvalue problem for the Laplace operator

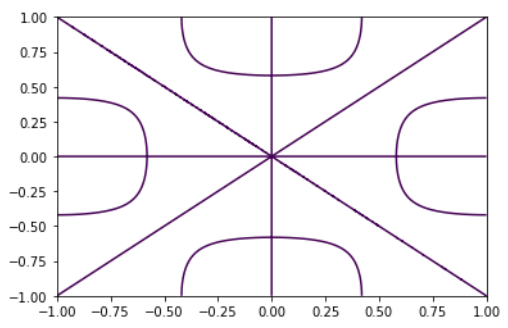

(a)

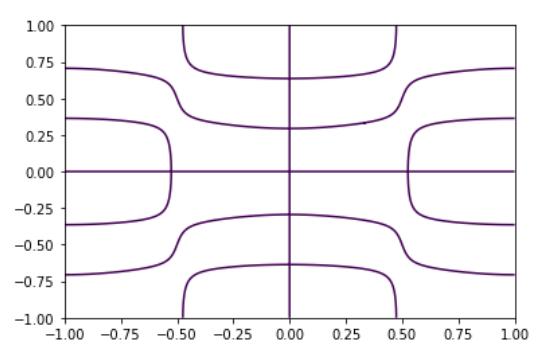

(c)

$$
\Delta s-\lambda s=0, \lambda=-\left(2 \pi \frac{f}{c}\right)^{2} .
$$

in a rectangle with Dirichlet boundary conditions

$$
\begin{aligned}
& s( \pm 1, y)=0,-1 \leq y \leq+1, \\
& s(x, \pm 1)=0,-1 \leq x \leq+1 .
\end{aligned}
$$

The solution to this problem is known [7]

$$
\begin{aligned}
& s_{m, n}(x, y)=a \sin (\pi n x) \sin (\pi m y)+ \\
& +b \sin (\pi m x) \sin (\pi n y), n, m=1,2,3, \ldots
\end{aligned}
$$

in a rectangle with Dirichlet boundary conditions where $a, b$ are constants,

$$
n^{2}+m^{2}=K ; K:=\left(2 \frac{f}{c}\right)^{2} .
$$

The following relationship is also takes place:

$$
\frac{c \sqrt{n^{2}+m^{2}}}{2}=f,
$$

Below we present the simulated Chladni figures for an elementary area with the size $1 \times 1$.

In particular, for $n=m$

$$
s=2(a+b) \sin \left(\frac{2 \pi f x}{c}\right) \sin \left(\frac{2 \pi f y}{c}\right) .
$$

That is, when the numbers at the frequency are equal, there is a simple dependence on the frequency, the parameters of the medium and the material.

\section{MODELING CHLADNI FIGURES BASED ON THE PROPOSED MODEL}

In this subsection, the solutions of equation (12) are presented for some values of the parameters $a, b, m, n$.

The values of the parameters were chosen from the point of view of practical interest, based on the effect of increasing the complexity of the pattern and the number of transitional lines of standing waves (inflection lines of the density gradient of the redistributed masses under the action of exciting frequency).

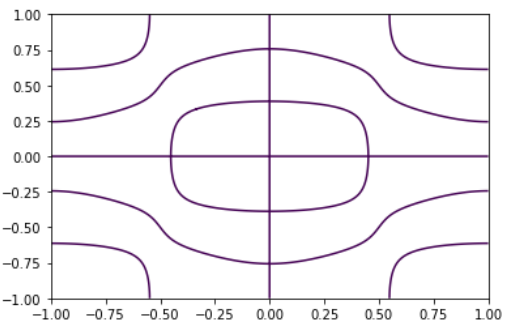

(b)

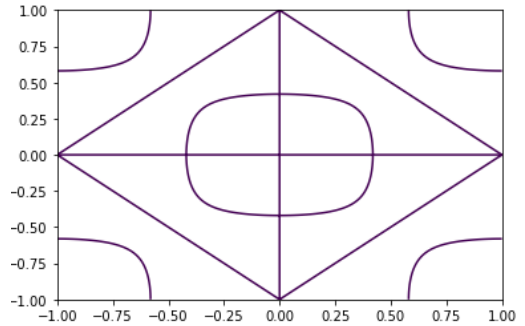

(d)

Fig. 2. Chladni figure with values: (a): $a=1 ; b=-1 ; m=2 ; n=3$; (b): $a=2 ; b=2 ; m=2 ; n=3$; (c): $a=2 ; b=-4 ; m=2 ; n=3 ;(\mathrm{d}): a=2 ; b=1 ; m=2 ; n=3$. 


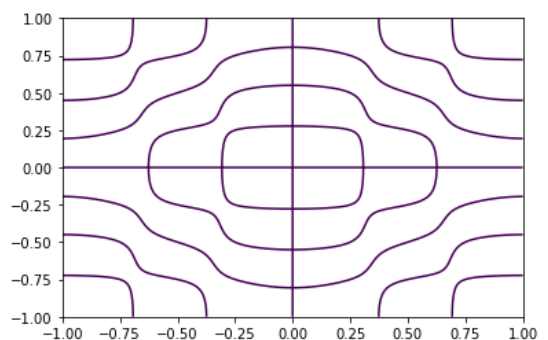

(a)

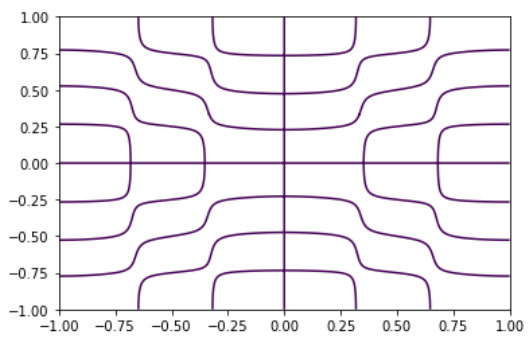

(b)

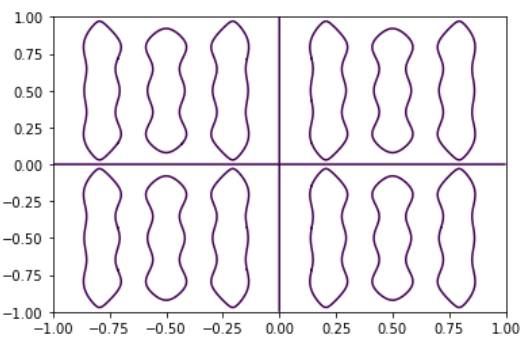

(c)

Fig. 3. Chladni figure with values: (a): $a=-2 ; b=-1 ; m=4 ; n=3 ;$ (b): $a=4 ; b=-1 ; m=4 ; n=3 ;(\mathrm{c}): a=-4 ; b=-1 ; m=1 ; n=7$.

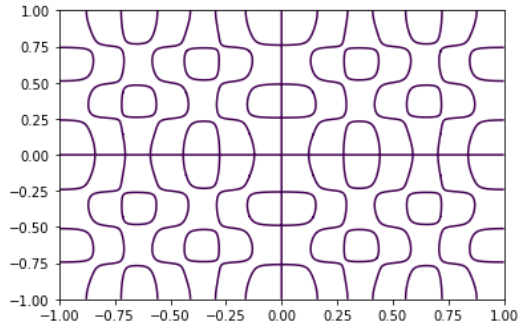

(a)

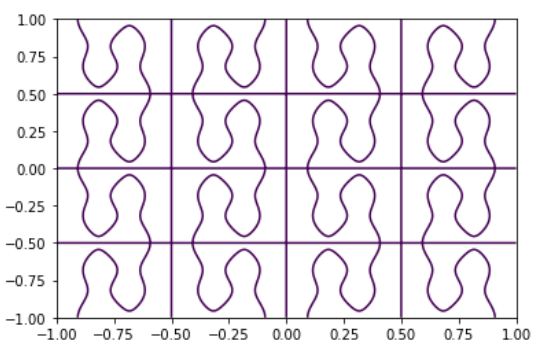

(b)

Fig. 4. Chladni figure with values: (a): $a=4 ; b=-1 ; m=4 ; n=7$; (b): $a=1 ; b=-3 ; m=8 ; n=2$.

By varying the values of the parameters, we simulate different configurations of metasurfaces. In particular $a$ and $b$ can assume negative values. So, varying the values of the parameters $a, b, c$, we control the characteristics of the material from which the plate is made. When simulating acoustic waves, these parameters set the rigidity [5]:

$$
D=\frac{2 E H^{3}}{3\left(1-V^{2}\right)^{\prime}}
$$

where $2 \mathrm{H}$ - plate thickness, E - Young's modulus, V Poisson's ratio. Stiffness is practically independent of frequency, excluding critical frequencies, where the generated pulses decay too quickly. As mentioned, the free term c determines the phase velocity, which changes only when there is dispersion of waves in the medium. In our case, we are dealing with geometric variance. In this case, the coefficient of elasticity in bending deformation increases with decreasing wavelength (increasing frequency) $k \sim \frac{1}{f}$. Since the coefficient of elasticity is directly proportional to Young's modulus, the effective

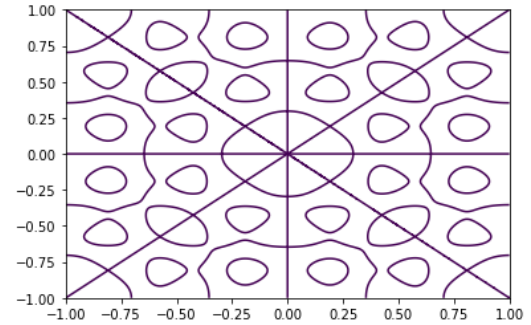

(a)

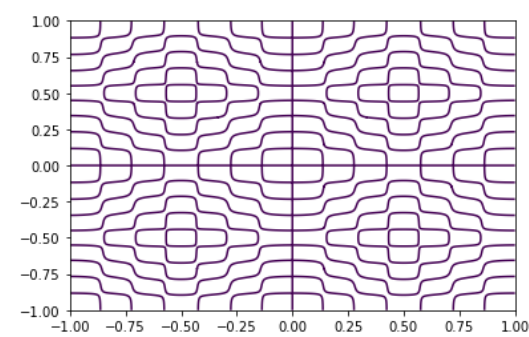

(b)

Fig. 5. Chladni figure with values: (a): $a=1 ; b=-1 ; m=8 ; n=3$; (b): $a=-4 ; b=-1 ; m=9 ; n=7$.

elasticity, as well as the wave speed, increase with decreasing wavelength. The speed of wave propagation in the medium is proportional to the square root of the frequency $(v \sim \sqrt{f})[7]$. We put all the constants equal to unity in order to estimate the dependence of our equation on the dispersion of the exciting wave (Fig. 6). So we have

$$
\frac{2 H^{3}}{3\left(1-V^{2}\right) f} \sin \left(2 \pi x f^{3 / 2}\right) \sin \left(2 \pi y f^{3 / 2}\right) \sim s
$$

Note that the coefficients of this equation are constants for a fixed experimental setting. For a rough (approximate) clarification of the nature of the dependence of the displacement coefficient $s$ on the generation frequency $f$, we set these constants equal to 1 , which is equivalent to rescaling the calculations.

Then we have:

$$
\frac{1}{f} \sin \left(f^{3 / 2}\right)^{2} \sim s
$$




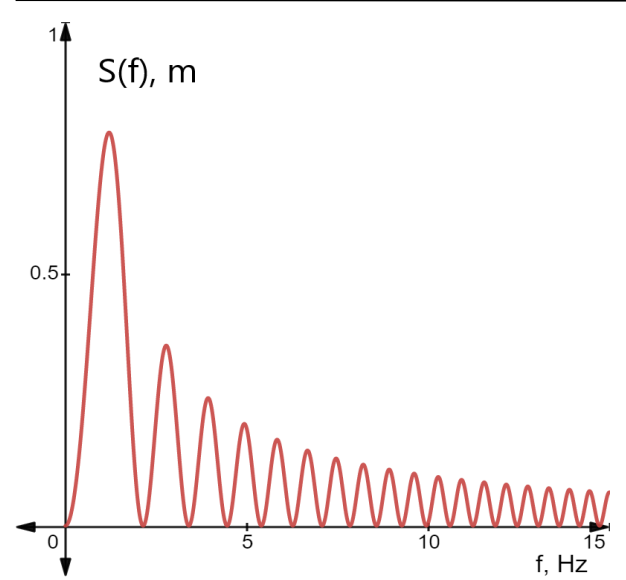

Fig. 6. Dependence of displacement coefficient $S$ on the generation frequency $f$.

If we are dealing with electromagnetic waves [11], then the parameters $a$ and $b$ determine the dielectric constant:

$$
\varepsilon(f)=\varepsilon^{\prime}+\varepsilon^{\prime \prime},
$$

where $\varepsilon$ 'is real part of the dielectric constant, $\varepsilon$ "is its imaginary part. The real part of the permeability characterizes the dependence of the phase velocity of wave propagation on the frequency, and the imaginary part characterizes the dependence of the attenuation of the amplitude. This means that the parameters $a$ and $b$ in representation (12) determine the imaginary part of the dielectric constant, and is the dependence of the phase velocity.

Disregarding resonant frequencies $\left(\varepsilon_{\infty}=0\right)$, we have:

$$
\begin{aligned}
\varepsilon^{\prime} & =\frac{\varepsilon_{s}}{1+f^{2} \tau^{2}}, \\
\varepsilon^{\prime \prime} & =\frac{\varepsilon_{S} f^{2} \tau^{2}}{1+f^{2} \tau^{2}},
\end{aligned}
$$

where $\varepsilon_{S}$ is static dielectric constant, $\tau$ is relaxation time.

Since $v=c / n(\varepsilon(f))$, where $c$ is the speed of light, $n$ is the medium refractive index, and $n=\sqrt{\varepsilon \mu}, \mu$ is magnetic permeability. Thus, by determining the static permeability of the material, we can control the configuration of metasurfaces. Substituting (16) and (17) into (12), we obtain the dependence of the displacement coefficient for electromagnetic waves on the generation frequency (Fig. 7).

$$
\frac{\varepsilon_{S} f^{2} \tau^{2}}{1+f^{2} \tau^{2}} \sin \left(2 \pi x \frac{\sqrt{\frac{\varepsilon_{S} \mu}{1+f^{2} \tau^{2}}}}{\mathrm{C}}\right) \sin \left(2 \pi y \frac{\sqrt{\frac{\varepsilon_{S} \mu}{1+f^{2} \tau^{2}}}}{\mathrm{C}}\right) \sim S,
$$

Similar to the previously considered procedure for roughly finding out the nature of the dependence of the displacement coefficient $\mathrm{S}$ on the generation frequency $f$, gives us the following:

$$
\frac{f^{2}}{1+f^{2}} \sin \left(\sqrt{\frac{1}{1+f^{2}}}\right)^{2} \sim s
$$

When creating a Chladni figure, the combination of the parameters of the dielectric plate, the surface electromagnetic material and the exciting frequency directly affect the displacement coefficient, as well as the rate of

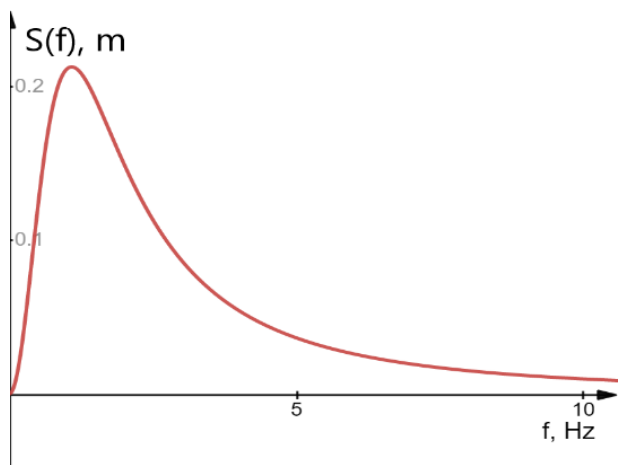

Fig. 7. Dependence of displacement coefficient $S$ on the generation frequency $f$ with dispersion of electromagnetic waves.

stabilization of the quick-moving material on the surface of the plate.

As one can see, the larger the coefficients at frequencies, the more inflection lines appear for standing waves, which is obvious, if we increase the generation frequency, we increase the number of standing wave peaks.

\section{CONCLUSIONS}

This paper presents an analytical model for constructing Chladni figures for a dielectric plate using eigenvalue problem for the Laplace operator in a rectangle with Dirichlet boundary conditions.

Chladni figures are constructed for different values of the parameters $a, b, c$ that appear in the stationary solution of the wave equation.

The dependence of displacement coefficient $S$ on generation frequency $f$ for acoustic and electromagnetic waves is modeled. The dependence of the electromagnetic characteristics of the material in the creation of Chladni figures is investigated.

It can be seen from the numerically simulated Chladni figures that increasing the exciting frequency, the number of inflection lines increases, which corresponds to real physical experiments.

From charts we can conclude that with increasing frequency, the displacement coefficient $\mathrm{S}$ is a damped sinusoid. This is influenced by wave dispersion as well as wave attenuation in the material.

The configuration of Chladni figures is determined by many characteristics, some of them in this model were intentionally omitted to simplify the presentation of the general view of the dependencies.

\section{REFERENCES}

[1]. M. I. Hossaina, N. Yumnam, W. Qarony, A. Salleo, V. Wagner, D. Knipp, Y.H. Tsang, "Non-resonant metal-oxide metasurfaces for efficient perovskite solar cells," Solar Energy, vol. 198, pp. 570-577, March 2020. DOI: 10.1016/j.solener.2020.01.082

[2]. Z. Liu, H. Zhong, H. Zhang, Z. Huang, G. Liu, X. Liu, G. Fu, C. Tang, "Silicon multi-resonant metasurface for full-spectrum perfect solar energy absorption," Solar Energy, vol. 199, pp. 360-365, March 2020. DOI: 10.1016/j.solener.2020.02.053

[3]. M.S. Islam, J. Sultana, M. Biabanifard, Z. Vafapour, M.J. Nine, A. Dinovitser, C.M.B. Cordeiro, B.W.-H. Ng, D. Abbott, 
"Tunable localized surface plasmon graphene metasurface for multiband superabsorption and terahertz sensing," Carbon vol. 158 , pp. 559 - 567, March 2020. DOI: 10.1016/j.carbon.2019.11.026

[4]. M. Faraday, "On a Peculiar Class of Acoustical Figures; and on Certain Forms Assumed by Groups of Particles upon Vibrating Elastic Surfaces," Philosophical Transactions of the Royal Society of London, vol. 121, pp. 299-340, 1831. DOI: $10.1098 / \mathrm{rspl} 1830.0024$

[5]. Timoshenko, S. and Woinowsky-Krieger, S., Theory of plates and shells, McGraw-Hill New York, 1959.

[6]. M.Zozyuk, D.Koroliouk, V.Moskaliuk, A.Yurikov and Yu.Yakymenko. Creation of quasiperiodic surfaces under the action of vibrating dielectric matrices, in ELNANO-2020, pp. 224 - 229, 2019. DOI: $10.1109 /$ ELNANO50318.2020.9088821

[7]. Mikhailov I. G., Soloviev V. A., Syrnikov Yu. P. Fundamentals of molecular acoustics. Nauka, M., 1964.

[8]. Isakovich M.A. General acoustics. Nauka, M., 1973.

[9]. M. O. Zozyuk, A. I. Yurikov, D. V. Koroliouk, Yu. I. Yakymenko. The Principle of Creating Quasiperiodic Surfaces under the Action of a Vibrating Dielectric Matrix, MicrosystElectronAcoust, 2020, vol. 25, no. 1, 5-10. DOI: 10.20535/25234455.mea.202632

[10]. Babych B., Borisova O., Machulianskyi O., Yakimenko Y., Rodionov M., Koroliouk D., Yakymenko Yu. Applications of Metal-dielectric nanocomposite structures in information systems. Comm. In ELNANO - IEEE 38th Conference on Electronics and Nanotechnology, 2018, pp. 96-100. DOI: $10.1109 /$ ELNANO.2018.8477509

[11]. D. Koroliouk, Classification of binary deterministic statistical experiments with persistent regression, Cybernetics and System Analysis, Springer NY, 2015, vol. 51, No. 4, 644-649. DOI: $\underline{10.1007 / \mathrm{s} 10559-015-9755-4}$

[12]. D. Koroliouk, D. Koroliouk, Adapted statistical experiments. Journal of Mathematical Sciences, Springer NY, Vol. 220 No. 5, February 2017, 615-623. DOI: 10.1007/s10958-016$\underline{3204-4}$

Надійшла до редакції 06 жовтня 2021 р. Прийнята до друку 22 грудня 2021 р.
[13]. D. Koroliouk, "Two component binary statistical experiments with persistent linear regression", Theory of Probability and Mathematical Statistics, 2015, v.90, pp.103- 114.

DOI: $10.1090 / \mathrm{tpms} / 952$

[14]. Koroliouk D., "Stationary statistical experiments and the optimal estimator for a predictable component" Journal of Mathematical Sciences, 2016, 214(2), pp.220-228. DOI: 10.1007/s10958-016$\underline{2770-9}$

[15]. Koroliouk, D.V., Koroliuk, V.S., Rosato, N., Equilibrium Processes in Biomedical Data Analysis: The Wright-Fisher Model. Cybernetics and Systems Analysis, 2014, 50(6), pp.890-897. DOI: $10.1007 / \mathrm{s} 10559-014-9680-\mathrm{y}$

[16]. Koroliouk, D., Statistical experiments in a balanced Markov random environment. Cybernetics and Systems Analysis, 2015, vol. 51, No. 5, pp.766-771. DOI: $10.1007 /$ s10559-015-9769-y

[17]. Koroliouk D., The problem of discrete Markov diffusion leaving an interval. Cybernetics and Systems Analysis, 2016, vol. 52, No. 4, pp.571-576. DOI: $10.1007 / \mathrm{s} 10559-016-9859-5$

[18]. D. Koroliouk Dynamics of Statistical Experiments, ISTEWILEY, London, 2020, 224 p. ISBN: 978-1-786-30598-5

[19]. D. Koroliouk, I. Samoilenko. Random evolutionary systems. asymptotic properties and large deviations, ISTE-WILEY, London, 2021, 350 p. ISBN: 978-1-119-85125-7

[20]. M. D. Waller. Chladni Figures. G. Bell, London, 1961.

[21]. H. R. Schwarz. Methode der finiten Elemente. B. G. Teubner, Stuttgart, Germany, 1991. ISBN: 9783519223498

[22]. T. Driscoll. Eigenmodes of isospectral drums. SIAM Review, vol. 39, No. 1, pp. 1-17, 1997. URL: https://tobydriscoll.net/publication/driscoll-eigenmodes-isospectral-drums-1997-a/driscolleigenmodes-isospectral-drums-1997-a.pdf

[23]. Mark Kac. Can one hear the shape of a drum? The American Mathematical Monthly, vol. 73, No. 4, pp. 1-23, 1966. DOI: $10.2307 / 2313748$

[24]. D.Koroliouk, M.Zozyuk, Yu.I.Yakymenko. The principle of creating quasiperiodic surfaces under the action of vibrating dielectric matrix, 2020, arXiv:2005.11053 [physics.app-ph]. 
УДК 620.3

\section{Моделювання фігур Хладні на прямокутній платівці}

Крисенко ${ }^{\mathrm{f}}$ П. I., ORCID 0000-0002-5612-9474

Зозюк M. I., ORCID 0000-0001-9116-7217

Юріков О. I., ORCID 0000-0001-8620-9902

Королюк Д. В., к.т.н., ORCID 0000-0003-2765-3450

Якименко Ю. І., д.т.н. проф., ORCID 0000-0002-8129-8616

Національний технічний університет України

«Київський політехнічний інститут імені Ігоря Сікорського» ROR 00syn5v21

Київ, Україна

Abstract-Стаття присвячена чисельному моделюванню створення поверхневих фігур під дісю збуджуючої частоти. Симуляція грунтусться на запропонованій аналітичній моделі створення метаповерхонь на прямокутних пластинах на основі ефекту Хладні перерозподілу «об'ємних» мас під дією стоячої хвилі.

Розглянуто зміщення поверхневих мас під дісю зовнішнього акустичного, або електромагнітного збудження частоти f, що описусться хвильовим рівнянням. Враховуючи стаціонарність рішення, що відповідас стоячій хвилі, а також граничні умови, модель зводиться до задачі на власні значення для оператора Лапласа в прямокутнику 3 граничними умовами Діріхле.

Вивчені співвідношення параметрів, які пояснюють зменшення розмірів елементів фігур Хладні при підвищенні частоти збудження.

Чисельне моделювання, при різних значеннях параметрів запропонованої моделі, ілюструє створення фігур перерозподілу поверхневих мас, що можна розглядати як можливий метод створення метаповерхень.

Ключові слова - стояча хвиля; фігури Хладні; метаповерхня. 